\title{
„Trochę za późno i za mało ale coś jest”. Polacy w Galicji wobec Aktu 5 listopada 1916 r.
}

Słowa kluczowe: pierwsza wojna światowa, Austro-Węgry, kwestia polska, Galicja

Keywords: World War I, Austria-Hungary, the Polish cause, Galicia (Eastern Europe)

\begin{abstract}
The outbreak of WWI offered hope to Poles from Eastern Europe's Galicia that the so-called Austria-Poland solution would ensue. In the face of military and political weakness of Austria-Hungary, the idea failed to take root. The proclamation of the Act of $5^{\text {th }}$ November 1916 indicated that the Polish state would be reconstructed under the auspices of the Second Reich. This arouse resentment among Poles living in Galicia who had hoped to be united with their compatriots in the Kingdom of Poland.
\end{abstract}

„Trochę za późno i za mało ale coś jest” - takim komentarzem powitał w swoim dzienniku informację o wydaniu Aktu 5 listopada 1916 r. chłopski działacz ludowy z Galicji Jakub Bojko ${ }^{1}$. Oddają one w jakimś stopniu nastawienie ogółu polskich mieszkańców Galicji wobec pierwszego międzynarodowego dokumentu zapowiadającego w czasie pierwszej wojny światowej odbudowę państwa polskiego. Akt przynosił radość, ale również rozczarowywał.

Przyczyn rozczarowania należy szukać w atmosferze początków wojny latem 1914 r., a nawet znacznie wcześniej. Niemal cała politycznie świadoma polska Galicja przed wybuchem Wielkiej Wojny żyła ideą austro-polską. Jak wspominał demokratyczny polityk Konstanty Srokowski: „Z Austrią i przez Austrię do Polski! - oto najistotniejsza treść tych wyobrażeń, które po wybuchu wojny zawładnęły umysłami

1 J. Bojko, Gorace stowa. Wybór pism, Kraków 2002, s. 179. 
w Galicji”’2. Opowiadali się za nią zarówno konserwatyści, demokraci, ludowcy, jak i lewica. Austrofilizm stanowił fundament działania polskiej reprezentacji w wiedeńskiej Radzie Państwa - Koła Polskiego. Konstytucyjna od 1861 r. naddunajska monarchia była jedynym państwem, które umożliwiało Polakom swobodny rozwój narodowy. Jej znaczenie wzrosło zwłaszcza po fiasku reformatorskiej działalności Aleksandra Wielopolskiego w Królestwie Polskim i klęsce powstania styczniowego. Już w obliczu wojny austriacko-pruskiej 1866 r. krakowski dziennik konserwatywny „Czas” kreślił przyszłe posłannictwo polityczne Galicji jako analogiczne do roli Piemontu w historii Włoch ${ }^{3}$. Wybitny polityk galicyjski Florian Ziemiałkowski porównywał ten zabór do arki, w której „Polskość się skryła i przy pomocy rządu i pracy naszej przetrwa burze barbarzyńskiej powodzi”’. W grudniu 1866 r. sejm krajowy galicyjski uchwalił słynny adres kończący się znamiennym zwrotem: „Z głębi naszych serc oświadczamy, że przy Tobie Najjaśniejszy Panie Stoimy i stać chcemy”. Sojusz z Franciszkiem Józefem nie tylko oddał władzę nad Galicją w ręce Polaków, ale przełożył się na wzrost ich znaczenia w państwie. Od lat sześćdziesiątych obejmowali oni najwyższe godności w państwie i uzyskali niebagatelne wpływy ${ }^{6}$.

Polityka austro-polska i lojalizm w stosunku do Habsburgów stały się w Galicji dogmatem, który na początku XX w. częściowo negowała jedynie nacjonalistyczna narodowa demokracja. Przed wybuchem pierwszej wojny światowej doszło zresztą na tym gruncie w obrębie tego obozu politycznego do gorących debat ${ }^{7}$. Część jej działaczy ostro oponowała przeciwko formowaniu ochotniczych oddziałów, które mogły zostać użyte do zainicjowania antyrosyjskiego powstania w Królestwie Polskim przy boku państw centralnych. Inni, jak Stanisław Głąbiński, widzieli możliwość współpracy z władzami monarchii. Przede wszystkim na gruncie postawy antyrosyjskiej.

2 K. Srokowski, N.K.N. Zarys historii Naczelnego Komitetu Narodowego, Kraków 1923, s. 78.

3 Czas, 15 V 1866, nr 108, s. 1; W. Suleja, Plany rozwiazania austro-polskiego w latach 1866-1913, [w:] Acta Universitatis Wratislaviensis, No 1135, Historia LXXVIII, Wrocław 1991, s. 3-35.

4 K. Bartoszewicz, Dzieje Galicji, jej stan przed wojna i „wyodrębnienie”, Warszawa, 1917, s. 159 .

5 Stenograficzne sprawozdania galicyjskiego Sejmu krajowego (dalej Sten. Spraw. Sejm.), I kadencja, 13 posiedzenie 4 sesji, 10 XII 1866, s. 161.

$6 \mathrm{Na}$ temat karier politycznych Polaków w monarchii habsburskiej w: W. Łazuga, Kalkulować... Polacy na szczytach C.K. Monarchii, Poznań 2013.

7 A. Wątor, Ziemianin-polityk. Tadeusz Cieński 1856-1925. Z dziejów konserwatyzmu wschodniogalicyjskiego, Szczecin 1997, s. 65-57. 
Galicja do wojny z Rosją „przygotowywała się” od kilku lat ${ }^{8}$. Z cichym i życzliwym poparciem władz Austro-Węgier liczących na wybuch wspomnianego antyrosyjskiego powstania w Królestwie Polskim . Popularność idei austro-polskiej wynikała nie tylko z politycznych kalkulacji i kombinacji, ale także z ogromnej popularności cesarza Franciszka Józefa wśród austriackich Polaków. Większość z nich traktowała go jako „swojego” monarchę ${ }^{10}$.

Konkretnym wyrazem politycznym austro-polskiego kierunku po wybuchu wojny stało się powołanie do życia Naczelnego Komitetu Narodowego (dalej NKN) w sierpniu 1914 r. Miał on koordynować i kierować akcją na rzecz urzeczywistnienia rozwiązania austro-polskiego. „Zbrojnym ramieniem” Komitetu stały się Legiony polskie. Z całej Galicji napływali ochotnicy i wsparcie finansowe. Mimo braku oficjalnej enuncjacji deklarującej wolę przyłączenia Królestwa Polskiego do monarchii habsburskiej bezdyskusyjnie zakładano, że jest to celem wojennym Wiednia. Franciszkowi Józefowi i jego państwu - jak wyjaśniał zaangażowany w działalność Komitetu Konstanty Srokowski - po prostu ufano ${ }^{11}$.

Galicjanie w ramach NKN rozpoczęli działania w kilku kierunkach:

1. Budowy ochotniczych formacji wojskowych u boku c. i k. armii, które czynem zbrojnym dowiodą proaustriackim pragnieniom i celom Polaków. Miały się składać zarówno z obywateli monarchii jak i Królestwa Polskiego (choć początkowo władze wojskowe monarchii nie wydały zgody na oficjalne prowadzenie tam werbunku).

2. Propagandy, zarówno w Galicji, ale przede wszystkim na terenie Królestwa Polskiego na rzecz tzw. rozwiązania austro-polskiego ${ }^{12}$. Dodajmy, że z biegiem czasu spore znaczenie uzyskał obszar Niemiec z Berlinem (tu działał delegat

8 W. Łazuga, Ostatni stańczyk. Michat Bobrzyński - portret konserwatysty, Poznań (b. r.), s. 119. 9 J. Gaul, Stużby wywiadowczo-informacyjne Austro-Wegier wobec radykalnego ruchu niepodleglościowego w Królestwie Polskim 1914-1918, Warszawa 2006, s. 51 n.; T. Nałęcz, Irredenta polska, Warszawa 1982; M. Wrzosek, Problem zbrojnego powstania przeciw Rosji na terytorium Królestwa Polskiego w 1914 r. w świetle dokumentów austro-węgierskiego ministerstwa spraw zagranicznych, [w:] Studia i materiały do historii wojskowości, t. XXXII, (1989), s. 271-309. $10 \mathrm{Na}$ ten temat w: R. Hołda, „Dobry władca”. Studium antropologiczne o Franciszku Józefie I, Katowice 2008.

11 K. Srokowski, N.K.N., s. $41 \mathrm{n}$.

12 A. Garlicka, Organizacja akcji prasowej Naczelnego Komitetu Narodowego, [w:] Rocznik Historii Czasopiśmiennictwa Polskiego, t. I, Wrocław 1964, s. 86-144. 
NKN-u Wilhelm Feldman), a następnie innych państw sojuszniczych i neutralnych (USA, Holandia, Szwecja, Bułgaria, Szwajcaria itd.).

3. Wpłynięcia na dyplomację monarchii w celu utrzymania jej na kursie austro-polskim. Politycy NKN zabiegali również o wydanie przez cesarza lub Ballhausplatz ${ }^{13}$ oficjalnej enuncjacji w sprawie przyłączenie Królestwa Polskiego w obręb monarchii habsburskiej. Było to istotne w kontekście pozyskania społeczeństwa Kongresówki, nieufnie (wbrew oczekiwaniom austriackich Polaków) nastawionego do Austro-Węgier ${ }^{14}$.

Następne lata to nieustanne zmagania i zabiegi o realizację powyższych dą$\dot{z ̇ e n ́}^{15}$. W politykę NKN zaangażowali się najważniejsi polscy politycy naddunajskiej monarchii. Ich marzeniem było tzw. rozwiązanie trialistyczne, czyli powołanie do życia (po zjednoczeniu Galicji z Kongresówka), Austro-Węgro-Polski. Istotnym balastem dla działalności komitetu był brak wspomnianej i niecierpliwie wyczekiwanej enuncjacji względem sprawy polskiej ze strony Wiednia. Wydanie takowej okazało się jednak problematyczne, skoro otwartym i bezkompromisowym przeciwnikiem trializmu był wpływowy premier Węgier István Tisza $^{16}$. Także postawa sojuszniczego Berlina pozostawała enigmatyczna. Tymczasem trudno było pozyskać opinię publiczną Królestwa Kongresowego podpierając się niejasnymi obietnicami. Niemniej, na przekór przeciwnościom, NKN pod kierownictwem niestrudzonego konserwatywnego polityka Władysława Leopolda Jaworskiego, mozolnie działał na rzecz idei austro-polskiej; prowadzono agitację, gromadzono fundusze, wydawano prasę, werbowano ochotników do Legionów. Jaworski znaczące wsparcie znalazł w osobie Leona Bilińskiego. Biliński zaliczał się do najbardziej wpływowych polityków polskich nad Dunajem. Ceniony i obdarzony zaufaniem przez Franciszka Józefa, wielokrotnie pełniący ministerialne funkcje, a w momencie wybuchu wojny stojący na czele tzw. wspólnego mini-

13 Nieformalne określenie austriackiej dyplomacji pochodzące od siedziby ministra spraw zagranicznych przy Ballhausplatz $1 \mathrm{w}$ Wiedniu.

14 J. Lewandowski, Królestwo Polskie wobec Austro-Węgier 1914-1918, Warszawa-Łódź 1986, s. 15-35.

15 W. Suleja, Orientacja austro-polska w latach I wojny światowej (do Aktu 5 listopada 1916 roku), Wrocław 1992.

16 Pisał o tym w liście do kierownika austriackiej dyplomacji Stefana Buriana już 11 VIII 1914 r., a więc jeszcze przed utworzeniem NKN-u. Głosu węgierskiej części monarchii w Wiedniu lekceważyć nie można było. Graf Stefan Tisza, Briefe (1914-1918), Bd. I, Berlin 1928, s. 50. 
sterstwa finansów, polityk ten posiadał znaczącą pozycję oraz liczne koneksje w Wiedniu mogące przydać się sprawie austro-polskiej. Mimo to przez półtorej roku wojny monarchia habsburska w kwestii polskiej oficjalnie milczała.

Tymczasem początek $1916 \mathrm{r}$. zaczął przynosić przeorientowanie w polityce Berlina. Zapewne niemieccy politycy nie posiadali jasno sprecyzowanej koncepcji co do przyszłości obszaru Królestwa Polskiego, ale zdecydowali, że nie oddadzą inicjatywy w tym względzie austriackiemu sojusznikowi ${ }^{17}$. Berlińska dyplomacja przystąpiła do konsekwentnej i wytrwałej ofensywy politycznej, która w efekcie doprowadziła do wytrącenia sprawy polskiej z ręki Ballhausplatzu. Podczas wizyty w Berlinie w kwietniu 1916 r. minister spraw zagranicznych monarchii habsburskiej István Burian zderzył się z nową rzeczowością polityczną. Kanclerz Theobald Bethmann-Hollweg oświadczył, że Niemcy rozwiązanie sprawy polskiej widzą w utworzeniu z Królestwa Polskiego tzw. państwa buforowego - związanego sojuszniczo z Rzeszą ${ }^{18}$. Był to zresztą powrót do tajnych planów z września 1914 r., gdy w obliczu sukcesów militarnych myślano o szerokim programie aneksji na wschodzie ${ }^{19}$.

Informacje o zmianie niemieckiego kursu stopniowo „przeciekały” do galicyjskiej opinii publicznej. Jeszcze w styczniu 1916 r. Jaworski nie miał wątpliwości co do przekazania Królestwa Polskiego monarchii, choć pod szeregiem obostrzeń. Po połowie marca 1916 r. zrezygnowany notował: „Jeśli rzeczywiście Austrii przypadnie Królestwo, będzie to cud"20. Intuicja go nie myliła. Informacje o niemieckich zakusach na ziemie polskie zaczęły pojawiać się coraz częściej. Galicyjscy Polacy w obliczu wyłaniającego się zagrożenia dla idei austro-polskiej uznali za konieczną konsolidację sił i udoskonalenie koordynacji działań. Obóz austro-polski, by wzmocnić swą pozycję, doprowadził do powołania na szefa NKN-u Leona Bilińskiego, pełniącego dotychczas funkcję prezesa Koła Polskie-

\footnotetext{
17 Na ten temat w: H. Lemke, Allianz und Rivalität. Die Mittelmachte und Polen im Ersten Weltkrieg (bis zur Februarrevolution), Berlin 1977; L. Grosfeld, Polityka państw centralnych wobec sprawy polskiej w latach 1914-1918, Warszawa 1962; D. Szymczak, Między Habsburgami a Hohenzollernami. Rywalizacja niemiecko - austro-węgierska w okresie I wojny światowej a odbudowa państwa polskiego, Kraków 2009.

18 S. Burian, Drei Jahre aus der Zeit meiner Amtsführung im Kriege, Berlin 1923, s. 74.

19 P. Mikietyński, Niemiecka droga ku Mitteleuropie. Polityka II Rzeszy wobec Królestwa Polskiego (1914-1916), Kraków 2009, s. 75-78; F. Fischer, Griff nach der Weltmacht. Kriegszielpolitik des kaiserlichen Deutschland 1914/1918, Düsseldorf 1967, s. 90-94.

20 W. L. Jaworski, Diariusz 1914-1918, Warszawa 1997, s. 87.
} 
go $^{21}$. Jaworski został wiceprezesem. W ten sposób miało dojść do ujednolicenia polityki Koła Polskiego i NKN-u, czego wielu członków polskiej frakcji parlamentarnej domagało się od dawna.

Tymczasem sytuacja polityczna rysowała się w coraz ciemniejszych barwach. O niemieckich koncepcjach utworzenia „niezależnego” państwa polskiego ze stolicą w Warszawie i bez Galicji galicyjscy Polacy uzyskali w miarę pewne informacje już z końcem wiosny/początkiem lata 1916 r. Pogłoski o tym nadchodziły zarówno z Wiednia, Berlina, jak i Warszawy ${ }^{22}$. Wiceprezydent austriackiej Rady Państwa, demokrata Ludomił German dostrzegał w lipcu 1916 r., że „sprawa jest w krytycznym punkcie”23. Z początkiem sierpnia endek Głąbiński pisał otwarcie wpływowemu działaczowi z Królestwa Kongresowego Janowi Steckiemu: „Głos Austrii w sprawie polskiej obecnie nic nie waży” ${ }^{24}$. To samo zakomunikował pod koniec tego miesiąca konserwatywnemu galicyjskiemu politykowi Zdzisławowi Tarnowskiemu Węgier Juliusz Andrássy, aspirujący nota bene do stanowiska szefa wiedeńskiej dyplomacji. Według Madziara, Buriana podczas ostatniej wizyty w Berlinie miano „zdyscyplinować” ${ }^{25}$. Z jednej strony niemieckie zakusy na Kongresówkę mogły niepokoić, ale z drugiej oczekiwano, że zmobilizują one Wiedeń do przychylniejszego spojrzenia na zabiegi i dążenia Polaków, co zaowocuje upragnioną enuncjacją. Liczono na ruch, inicjatywę, asertywność. Wychodząc z takiego założenia Polacy poprosili ministra spraw zagranicznych Buriana o przyjęcie deputacji w celu omówienia przyszłości Królestwa Polskiego. Dodatkowo ex-prezes Koła Polskiego i prezydent Krakowa Juliusz Leo domagał się, aby powołano przy rządzie wiedeńskim specjalnego polskiego pełnomocnika/doradcę do spraw polskich. Wskazywał na nazwiska byłego namiestnika Galicji Michała

\section{Czas, 24 III 1916, nr 153, s. 3.}

22 Notatka o niepokojących relacjach z Warszawy w dzienniku Zdzisława Tarnowskiego (1862-1937) z 3 VII 1916 r. Archiwum Narodowe w Krakowie oddział Wawel (dalej: ANKr), Archiwum Dzikowskie Tarnowskich, Diariusz Zdzistawa Tarnowskiego, teczka 625. Sprawozdanie Wilhelma Feldmana z Berlina z 31 V 1916, Papiery Stanisława Kota, Biblioteka Jagiellońska (dalej BJ), teczka 109/83.

23 L. German, Pamiętniki z lat 1916-1918, Lwowska Naukowa Biblioteka im. W. Stefanyka NAN Ukrainy (dalej LNB) rkps 6415, teka 1, k. 71.

24 S. Głąbiński do J. Steckiego z 3 VIII 1916, Korespondencja Jana Steckiego, rkps. 1212, Biblioteka Katolickiego Uniwersytetu Lubelskiego (dalej BKUL), k. 169.

25 Notatka Zdzisława Tarnowskiego z 27 VII 1916 r., Diariusz Zdzistawa Tarnowskiego, ANKr. 
Bobrzyńskiego lub dyplomaty Adama Tarnowskiego. Sytuacja przedstawiała się poważnie. Jaworski obawiał się, że w razie przekreślenia idei austro-polskiej, żaden człowiek w Galicji nie powie, „przy Tobie Najjaśniejszy Panie stoimy i stać chcemy" ${ }^{26}$.

Rzecz się rozstrzygnęła w czasie wizyty kanclerza Bethmanna-Hollwega w Wiedniu 11 i 12 VIII 1916 r. Tu zapadła definitywna decyzja o utworzeniu „samodzielnej” Polski, co było równoznaczne z zanegowaniem austro-polskiego rozwiązania. Co ciekawe, przywoływany German o mającym niebawem nastąpić ogłoszeniu niepodległości Polski słyszał już 14 sierpnia w czasie pobytu w Kryni$\mathrm{cy}^{27}$, a więc dwa dni po odjeździe Bethmanna-Hollwega z Wiednia! Po połowie miesiąca sygnały o polskiej „niepodległości” bez Galicji zaczęły napływać coraz szerszym nurtem. Oficjalnie jako jednemu z pierwszych Polaków Burian przekazał tę informację Zdzisławowi Tarnowskiemu 4 IX 1916 r. ${ }^{28}$ Równocześnie austriacki premier Karl Stürgkh powiadomił o wiedeńskich rozstrzygnięciach ministra dla Galicji Zdzisława Morawskiego. Premier zdawał sobie sprawę z ogromnego rozczarowania galicyjskich Polaków i obawiał się wybuchu antyaustriackiej irredenty w tej prowincji, podobnie jak szef dyplomacji ${ }^{29}$. Dogmatem polityki galicyjskich Polaków było przecież zakładane włączenie pod berło Franciszka Józefa ziem Królestwa Polskiego. Czy teraz mogli oni bez emocji przyglądać się jak powstaje tuż obok, i bez nich, państwo polskie? Stürgkh musiał Polaków jakoś udobruchać. Zamierzał to osiągnąć za pomocą rozszerzenia dotychczasowej autonomii Galicji, choć nie - co podkreślał Morawski - konstytucyjnego wyodrębnienia kraju ${ }^{30}$. To natomiast zasugerował Burianowi były namiestnik Galicji i czołowy orędownik austro-polskiej opcji Michał Bobrzyński ${ }^{31}$. Byłby to de facto powrót to postulatów rezolucji galicyjskiej z września 1868 r. ${ }^{32}$ Minister spraw

26 W. L. Jaworski, Diariusz, s. 112.
27 L. German, Pamiętniki, LNB, k. 87.
28 A. Czedik, Zur Geschichte der k.k. österreichischen Ministerien 1861-1916, B. IV, Zeitabschnitt 1908-1916, Teschen-Wien-Leipzig 1917, s. 530-531.

29 S. Burian, Drei Jahre aus der Zeit, s. 80.

30 D. Szymczak, Zdzisław Morawski - Wielkopolanin, który został austriackim ministrem. Zapiski Zdzistawa Morawskiego z lat 1914-1916, [w:] Niepodległość, t. LXVI, Warszawa 2015, s. 262.

31 S. Burian, Drei Jahre aus der Zeit, s. 80.

32 Zgodnie z tą rezolucją Galicja miała uzyskać w obrębie Przedlitawi konstytucyjnie zagwarantowane wyodrębnienie, które dawałoby tej prowincji pozycję podobną do zajmowanej 
zagranicznych propozycję zaakceptował. Niebawem jednak premier Stürgkh padł ofiarą zamachu. W ten sposób rozwiązanie kwestii polsko-galicyjskiej stało się jednym z głównych wyzwań dla nowego rządu Ernsta Koerbera. Równolegle z aktem zapowiadającym odbudowę niepodległej Polski miał zostać proklamowany przez cesarza akt wyodrębnienia Galicji. Opublikowano go 5 listopada z datą wydania sygnowaną na 4 listopada ${ }^{33}$.

Fiasko rozwiązania austro-polskiego było równoznaczne z początkiem końca firmującego je NKN-u, który w ten sposób tracił zasadność swego istnienia. Wysunąć się musiało także pytanie o przyszłość Legionów ${ }^{34}$. Podstawowym dążeniem polskich polityków z Galicji stało się przekształcenie tej formacji w kadry przyszłej armii polskiej a więc przekazanie jej Królestwu Polskiemu. Pozwoliłoby to na utrzymanie galicyjskiego wpływu w przyszłym państwie polskim. Tymczasem Austriacy, obawiając się konsekwencji wynikłych z przegranej w sprawie polskiej, zdecydowali się na utworzenie z Legionów osobnego Polskiego Korpusu Posiłkowego. Oznaczało to spełnienie postulatu od dawna stawianego przez NKN. Nota bene wywołało irytację Rzeszy, którą o sprawie powiadomiono w ostatniej chwili ${ }^{35}$.

Informacje o postanowieniach wiedeńskich z sierpnia 1916 r. musiały wstrząsnąć firmamentem polskiej polityki w Galicji. Cała dotychczasowa, tak wytrwale i konsekwentnie prowadzona przez austrofilów polityka - jak słusznie podnosił później ich przeciwnik Roman Dmowski - powędrowała ad acta ${ }^{36}$. Na 3 i 4 października zwołano do Krakowa, pod przewodnictwem Bilińskiego, Koło Sejmowe, gdzie po raz pierwszy oficjalnie zakomunikowano, że rozwiązanie austro-polskie upadło. Prezes Koła Polskiego główną winą obarczył ministra spraw zagranicznych Buriana. Nie uchroniło go to przed oskarżeniami i burzliwą debatą. Ostro wystąpił przywódca socjalistów Ignacy Daszyński; zarówno przeciw

przez Chorwację w ramach Zalitawii. S. Pijaj, Między polskim patriotyzmem a habsburskim Lojalizmem. Polacy wobec przemian ustrojowych w monarchii habsburskiej (1866-1871), Kraków 2003, s. 228.

33 Wiener Zeitung, 5 XI 1916, nr 254, s. 1.

$34 \mathrm{Na}$ temat dalszych losów Legionów polskich w: J. Snopko, Finat epopei Legionów Polskich 1916-1918, Białystok 2008.

35 Z. Grabowski, Powołanie Polskiego Korpusu Positkowego jak próba sprostania polskim aspiracjom niepodlegtościowym, [w:] Między Wiedniem a Lwowem. Referaty polsko-austriackiej sesji poświęconej 80 rocznicy wybuchu I wojny światowej. Warszawa 17 XI 1914, red. A. Rzepniewski, Warszawa 1994, s. 61.

36 R. Dmowski, Polityka polska i odbudowanie państwa, t. I, Warszawa 1988, s. 323. 
monarchii, jak i Bilińskiemu (choć ten ostatni twierdził w pamiętniku, że został przez słynnego „trybuna ludu” potraktowany „dobrotliwie”) ${ }^{37}$. Emocji nie brakowało i w innych wystąpieniach, zwłaszcza posła ludowego Mikołaja Reya. Politycy narodowo-demokratyczni wykorzystali okazję, by zaatakować politykę NKN-u, w którym zresztą nie byli reprezentowani i de facto go zwalczali. Poseł Władysław Dębski stwierdził, że jego stronnictwo wyklucza jakiekolwiek rozwiązanie sprawy polskiej, które oznaczałoby rezygnację z którejś z części Polski, co uderzało zarówno w niemiecką koncepcję państwa buforowego (Pufferstaatu) ${ }^{38}$, jak i rozwiązanie austro-polskie. Zarzucił ponadto Kołu Polskiemu, że realizuje nie własną politykę, lecz „austriackiej biurokracji i rządu w Berlinie”39. Upadek rozwiązania austro-polskiego oznaczał nie tylko przekreślenie całej dotychczasowej działalności NKN-u i Legionów, ale również kompromitację galicyjskich polityków w Warszawie i Lublinie, gdzie cały czas zapewniali, iż sprawa przyłączenia Królestwa Polskiego do Austrii jest przesądzona. Koło Sejmowe uchwaliło wobec szefa dyplomacji votum nieufności, co oczywiście miało tylko symboliczne znaczenie, ponieważ od 1914 r. Rada Państwa nie obradowała. Był to jednakże chyba pierwszy przypadek, by polscy parlamentarzyści postawili taki wniosek wobec kierownika polityki zagranicznej monarchii. Manifestacja wywołała naturalnie zaniepokojenie w Wiedniu. Franciszek Czaki - współpracujący z NKN pracownik austriackiego ministerstwa spraw zagranicznych donosił, że październikowa uchwała Koła Sejmowego nad Dunajem rozpaliła obawy przed polską irredentą, a cenzura zaczyna krzywym okiem spoglądać na wszelkie artykuły mówiące o połączniu Królestwa z Galicją ${ }^{40}$.

Chwilowo jednak kwestia enuncjacji w sprawie przyszłości Kongresówki została „zamrożona”. Wiązało się to z ożywieniem nadziei Bethmanna-Hollwega na separatystyczny pokój z Rosją. Po kilku tygodniach zostały one rozwiane. W czasie narad w niemieckiej Kwaterze Głównej w Pszczynie w drugiej połowie października podjęto decyzję o publikacji aktu zapowiadającego niepodległość Królestwa Polskiego. Datę wyznaczono na niedzielę 5 listopada. Tego dnia punk-

37 L. Biliński, Wspomnienia i dokumenty, t. II, 1915-1922, Warszawa 1925, s. 101-103; I. Daszyński, Pamiętniki, t. II, Warszawa 1957, s. 243-245.

38 Zgodnie z tą koncepcją satelickie Królestwo Polskie pełniłoby rolę „buforu” pomiędzy Rzeszą a cesarstwem rosyjskim.

39 A. Wątor, Narodowa demokracja w Galicji do 1918 roku, Szczecin 2002, s. 335.

40 Raport Franciszka Czakiego z Wiednia z 6 X 1916, ANKr, Archiwum NKN, mikr. 100.211, k. 86 . 
tualnie o godzinie 12.00 na Zamku Królewskim w Warszawie oraz w gmachu generał-gubernatorstwa w Lublinie odczytano proklamację niepodległości Polski.

W jaki sposób przyjęto te wydarzenia w zaborze austriackim? Zdystansowany do naddunajskiej monarchii Głąbiński zwracał uwagę w swych pamiętnikach, że polskie społeczeństwo w Galicji zareagowało odmiennie niż tutejsi politycy na październikowym Kole Sejmowym. Dominowało uczucie radości, nie spotykało się gestów oburzenia. Przynajmniej początkowo. „Widziałem we Lwowie -pisał Głąbiński, który jako cichy zwolennik ententy do aktu odnosił się bardzo sceptycznie - jak ludzie ze łzami radości padali sobie w objęcia i gratulowali sobie, że nareszcie powstanie Polska do nowego życia" ${ }^{41}$. Podobnie o nastrojach inteligencji polskiej na Śląsku Cieszyńskim pisała Zofia Kirkor-Kiedroniowa. Także tu wydarzenia warszawskie i lublińskie „wywołały wielką i bodaj szczerą radość” ${ }^{2}$. Świadectwa te potwierdza w swej pracy Od autonomii do niepodlegtości Jerzy Z. Pają $k^{43}$. Ze sporym entuzjazmem zareagowała prasa galicyjska, choć tu akcenty były już bardziej wyważone. „Czas” w związku z Aktem 5 listopada zauważał: „Zarysowuje się przed nami możliwość podjęcia pracy w tym mniej więcej punkcie, w jakim prowadziliśmy ją 100 lat temu - ale niewątpliwie w znacznie korzystniejszych okolicznościach”44. Autor tekstu podnosił, że w przeciwieństwie do 1815 r. tym razem dwie spośród trzech polskich dzielnic znajdują się w korzystnym położeniu. Wzywał, aby nie poddawać się sceptycyzmowi i wykorzystywać każdą sprzyjającą sposobność ku budowie Polski. Królestwo Polskie uzyskało ponadto możliwość zorganizowania wojska polskiego - „najważniejszego z państwowo-twórczych elementów”. Polacy w Galicji w nowej sytuacji również muszą myśleć i działać racjonalnie poświęcają formę dla treści. Było tu jasne odwołanie do aktu wyodrębnienia Galicji, które powinno iść w kierunku tworzenia własnego państwa, choćby nieformalnie. W kolejnym numerze padło gorzkie stwierdzenie, iż mimo wszystko, „nie możemy się obronić uczuciu zawiedzionej nadziei” ${ }^{45}$. Ostrze zarzutów z powodu fiaska idei austro-polskiej skierowano jednak przeciw Królewiakom, gdyż zabrakło ich stanowczego oświadczenia się za tą koncepcją. W rezultacie wygrał gorszy modus rozwiąza-

\footnotetext{
41 S. Głąbiński, Wspomnienia polityczne. Część druga. Wojna Światowa, Pelplin 1939, s. 254.

42 Z. Kirkor-Kiedroniowa, Wspomnienia, cz. II, Ziemia mojego męża, Kraków 1988, s. 219.

43 J. Z. Pająk, Od autonomii do niepodlegtości. Kształtowanie się postaw politycznych i narodowych społeczeństwa Galicji w warunkach Wielkiej Wojny 1914-1918, Kielce 2012, s. 178-187. 44 Czas, 6 XI 1916, nr 560, s. 1.

45 Tamże, 6 XI 1916, nr 561, s. 1.
} 
nia sprawy polskiej. Niemniej trzeba wykorzystać wszelkie okoliczności i budować rzeczywistą niepodległość. Jest ona możliwa - co szczególnie mocno podkreślano - tylko przy wsparciu Austro-Węgier. „Czas” wzywał zatem do dostrzeżenia powagi chwili i „dojrzałości politycznej”.

O wiele chłodniej akt został przyjęty przez socjalistyczny „Naprzód”. Dziennik poświęcił wydarzeniu krótki tekst i w zasadzie ograniczył się do przedruku sprawozdań prasowych bądź komunikatów. Akt 5 listopada potraktowano jako ważną „obietnicę” i „prowizorium”, którego ramy „powinna też wypełnić polska zorganizowana wola do pełnego państwowego życia” ${ }^{46}$. Dziennikarz, publicysta i polityk Konstanty Srokowski (mocno związany z NKN-em) w demokratycznej „Nowej Reformie” wystąpił z emfatycznym artykułem zatytułowanym: „Odbudowa Polski”. Autor prorokował, że dzień 5 listopada przejdzie do historii Polski pod mianem „Wielkiego Dnia”. Głównym zaś problemem narodu polskiego w przełomowej chwili będzie jak poradzić sobie z brzemieniem szczęścia „dawno śnionego zmartwychwstania ${ }^{47 ”}$. Przez lata niewoli przyzwyczaił się on bowiem do bycia nieszczęśliwym. Czy Polacy potrafią opanować sztukę bycia szczęśliwymi? Srokowski radził odrzucić marzenia - choć usprawiedliwione i zrozumiałe - o Wielkiej Polsce, a cieszyć się z tego, co mimo wielu przeciwności uzyskano. Pisał zresztą o powstającym państwie jako kolebce nowej Polski i o konieczności pracy nad jej rozwojem. Do pracy wzywał również katolicki „Głos Narodu”48.

Ludowy „Piast” donosił, że po 122 latach Polska powraca znów na mapę Europy, co jest „faktem, którego się już nie da usunąć”49. Zarazem nie omieszkano dodać, iż oczekiwano na inne rozwiązanie sprawy polskiej. Patetycznie unosił się demokratyczno-ludowy „Kurier Lwowski”: „Kto nie wierzył w Opatrzność w dziejach, musiał uwierzyć, gdy wśród gigantycznych zmagań ozwało się nagle miano: Polska” i dodawał: „Z dniem dzisiejszym Polska (...) staje się znów odrębnym organizmem państwowym”50 "Ilustrowany Kurier Codzienny” zauważył, że pierwszym dobroczynnym skutkiem Aktu 5 listopada jest zapowiedź wyodrębnienia Galicji51 . Bliski endecji „Rok Polski” wskazywał na kolejny krok, jakim musi być uznanie

\footnotetext{
46 Orędzia monarchów, Naprzód, 6 XI 1916, nr 308, s. 1.

47 Odbudowa Polski, Nowa Reforma, 7 XI 1916, nr 561, s. 1.

48 Urót nowej ery narodu, Głos Narodu, 6 XI 1916, nr 546, s. 1.

49 Odbudowanie państwa polskiego, Piast, 12 XI 1916, nr 46, s. 1.

50 Polska, Kurier Lwowski, 5 XI 1916, nr 554, s. 1.

51 W momencie dziejowym, Ilustrowany Kurier Codzienny, 15 XI 1916, nr 228, s. 1.
} 
międzynarodowego charakteru sprawy polskiej, jako mocnej podstawy, „na której możemy budować naszą przyszłość" 52 . Co więcej, jedynym warunkiem trwałego uregulowania życia politycznego w Europie będzie restytucja Polski.

Wiceszef NKN Jaworski mimo porażki swego kierunku doceniał znaczenie Aktu 5 listopada. „Trumf i szczęście” - notował w dzienniku ${ }^{53}$. Współpracownik NKN-u, wybitny historyk Jan Dąbrowski konstatował natomiast: „Prawda, jesteśmy my z Galicji zawiedzeni, na boku. Ale to rzecz uczucia. Rozum mówi nam, że mamy zdobycz wielką"54. Ów rozum i chłodna kalkulacja kazały konserwatystom apelować do polityków z Królestwa Polskiego, aby popierali sprawę utworzenia państwa polskiego i dążyli do jego szybkiej organizacji. Nawet w okrojonej postaci ${ }^{55}$.

Co do ludowców to - jak wspominał jeden z liderów ruchu Witos - byli oni w ocenie aktu podzieleni ${ }^{56}$. Część uważała go za pierwszy krok ku odbudowie państwa, inni wskazywali, że jest raczej dowodem słabości Niemiec, a w związku z tym ich nieszczerości i perfidii ${ }^{5}$. Sam Witos dostrzegał $\mathrm{w}$ akcie inne dobre strony, obojętną dotąd część społeczeństwa zmusił do myślenia. Negatywnie do aktu odnosiła się naturalnie narodowa-demokracja ${ }^{58}$.

Z okazji wydania aktu zorganizowano w Galicji liczne uroczystości. Specjalną mszę odprawiono 8 listopada w katedrze na Wawelu. Oficjalne relacje prasy były entuzjastyczne ${ }^{59}$. W rzeczywistości biskup Adam Sapieha nie odśpiewał Te Deum, uniwersytet reprezentował ponoć tylko rektor Władysław Szajnocha, Dzwon Zygmunta rozbujali samowolnie legioniści, nie kłopocząc się z prośbą o zgodę władz kościelnych, za to na ulicach rozlegały się gromkie okrzyki na cześć Piłsudskiego. $\mathrm{Na}$ obecności i entuzjazmie tłumu wobec tego ostatniego skoncentrowała się re-

\footnotetext{
52 W. Karniowski, Odrodzenie zasady narodowości, Rok Polski, XI 2016, nr 9, s. 45.

53 W. L. Jaworski, Diariusz, s. 144.

54 J. Dąbrowski, Dziennik 1914-1918, Kraków 1977, s. 85.

55 S. Dzierzbicki, Pamiętniki z lat wojny 1915-1918, Warszawa 1983, s. 188.

56 Początkowo np. entuzjastą aktu był poseł ludowy Włodzimierz Tetmajer. J. Rączkowski, Wśród polityków i artystów (ze wspomnień redaktora), Warszawa 1969, s. 335.

57 W. Witos, Moje wspomnienia, Warszawa 1988, s. 374-375; Z. Lasocki, Polskie Stronnictwo Ludowe w czasie wojny światowej, Katowice 1937.

58 A. Wątor, Narodowa Demokracja w Galicji, s. 336.

59 Obchód w Krakowie, Głos Narodu, 8 XI 1916 nr 550, s. 1-2; Manifestacja miasta Krakowa, Nowa Reforma, 8 XI 1916, nr 564, s. 1.
} 
lacja socjalistycznego „Naprzodu”60. Lewica wykorzystała okazję do promowania Piłsudskiego, którego imię „twórczo” włączono nawet do tekstu odśpiewywanego „Mazurka Dąbrowskiego”. Nachalne eksponowanie zasług i osoby Komendanta budziło niesmak u konserwatywnie nastawionych uczestników uroczystości. Obecnego na Wawelu ziemianina Adama Stadnickiego drażniło wznoszenie okrzyków „niech żyje Piłsudski”, zamiast „niech żyje Polska”61. Jak zwraca uwagę Przemysław Marcin Żukowski - krakowska inteligencja przyjęła Akt 5 listopada „jeśli nie obojętnie to na pewno chłodno lub z dystansem czy rezerwą"62.

Jak było w innych miastach? W wielu z nich zaplanowano uroczyste zabrania władz, i patriotyczne manifestacje ${ }^{63}$. Przykładem świecił Lwów. W stolicy Galicji około południa 5 listopada samolot pilotowany przez oficera Legionów rozrzucił ulotki z tekstem proklamacji ${ }^{64}$. O podniosłej atmosferze nad Pełtwią donosił „Kurier Lwowski”. Relacjonowano o tłumach mieszkańców gromadzących się wokół redakcji czasopism w oczekiwaniu na nowe wieści ${ }^{65}$. Przy pomniku Mickiewicza wygłaszano patriotyczne mowy, samorzutnie utworzył się uroczysty pochód. Kilka dni później - 9 listopada - odbyła się oficjalna celebra proklamacji. W katedrze odprawiono uroczyste nabożeństwo z udziałem arcybiskupa Józefa Bilczewskiego i najważniejszych dostojników galicyjskich, państwowych oraz wojskowych ${ }^{66}$. Inaczej relacjonował wydarzenia związane z ogłoszeniem Aktu 5 listopada „krytyczny” wobec monarchii habsburskiej rzeszowianin Wincenty Daniec. Pisząc w dzienniku o uroczystości w Rzeszowie miał wrażenie „sztucznie

60 Ku uczczeniu komendanta Józefa Pitsudskiego, Naprzód, 9 XI 1916, nr 311, s. 1. „Do wielkiej radości dnia 5 listopada nie miałby naród dzisiaj moralnego prawa, gdyby nie Czyn Piłsudskiego z dnia 6 sierpnia i wysnuty z niego czyn Legionów".

61 A. Stadnicki, Wspomnienia, Nowy Sącz 2015, s. 62.

62 P.M. Żukowski, Inteligencja krakowska wobec Aktu 5 listopada 1916 roku, [w:] Akt 5 listopada 1916 roku i jego konsekwencje dla Polski i Europy, red. J. Kłaczkow, K. Kania, Z. Girzyński, Toruń 2016, s. 79.

63 K. Ruszała, Wielka Wojna w matym mieście. Gorlice w latach 1914-1918, Kraków 2015, s. 134; Uroczysty obchód proklamowania niepodlegtości Królestwa Polskiego i wyodrębnienia Galicji $w$ Przemyślu, Echo Przemyskie, 12 XI 1916, nr 91, s. 2-4; Uroczysty obchód proklamowania niepodlegtości Królestwa Polskiego i wyodrębnienia Galicji w Rzeszowie, Głos Rzeszowski, 19 XI 1916, nr 48, s. 2-3.

64 J. Z. Pająk, Od autonomii do niepodlegtości, s. 180.

65 Nastrój w mieście, Kurier Lwowski, 5 XI 1916, nr 554, s. 5; Obchód 5 listopada we Lwowie, Nowa Reforma, 7 XI 1916, nr 562, s. 1.

66 Obchody we Lwowie, Gazeta Lwowska, 10 XI 1916, nr 255, s. 2. 
przygotowanej roboty" ${ }^{67}$. Okolicznościowe msze odbyły się także w wiejskich kościołach, ale chłopski pamiętnikarz Józef Słomka twierdził, że akt przeszedł tu „bez silniejszego wrażenia”68.

Mimo wszystko w Galicji przeważały pozytywne odczucia w związku z wydaniem Aktu 5 listopada. Politykom obawiającym się oskarżeń o fiasko austro-polskiej polityki chwilowo kamień spadł z serca. Wszystko to sprawiło, że zebranie Koła Sejmowego 12 XI 1916 r. w Krakowie przebiegało już w innej atmosferze. Oficjalną mowę wygłosił Leon Biliński. Podnosił on historyczne i kulturalne prawo Polaków do posiadania państwa. Program galicyjskich Polaków nie ziścił się, ale Akt 5 listopada jest tak doniosłym, że „w tej dziejowej chwili muszą zniknąć wszelkie różnice programów” ${ }^{69}$. Równolegle prezes Koła podziękował cesarzowi za wyodrębnienie Galicji. Niebawem polscy politycy pod kierunkiem Michała Bobrzyńskiego jako ministra dla Galicji przystąpili do opracowania konstytucji dla Galicji oraz procedury jej wyodrębnienia ${ }^{70}$.

Polacy galicyjscy faktycznie z połączenia z Królestwem nigdy nie zrezygnowali. Wspominany Dąbrowski zarzekał się w dzienniku, że od programu tego nie odstąpią, zanim nie zdecyduje o tym traktat pokojowy ${ }^{71}$. Dopóki trwała wojna, wszystko było jeszcze możliwe. Zwłaszcza korzystną pod tym względem okolicznością - zdaniem Jaworskiego - była paradoksalnie śmierć Franciszka Józefa 21 XI 1916 r. ${ }^{72}$ Uwalniało to Polaków od owego „specjalnego”, „osobistego” (jak mówiono) stosunku z monarchą, ufundowanego na adresie grudniowym z 1866 r. Zachodniogalicyjski konserwatysta Jan Hupka stawiał już we wrześniu 1916 r., pachnącą rewolucyjnie tezę, że Polacy będą tylko czekać na możliwość oderwania się od Austrii. Nawet po nadaniu specjalnej autonomii. „W przeciągu lat niewielu zadepczemy granicę" - zapowiadał Hupka ${ }^{73}$.

67 W. Daniec, Nasz ostatni biuletyn wojenny, cz. 2, Rzeszów 1931, s. 77.

68 J. Słomka, Pamiętnik włościanina. Od pańszczyzny do dni dzisiejszych, Warszawa 1983, s. 252.

69 Mowa prezesa Bilińskiego, Piast, 19 XI 1916, nr 47, s. 2.

70 D. Szymczak, Zmierzch galicyjskiego austrofilizmu i idei austro-polskiej. Michat Bobrzyński jako minister dla Galicji i kwestia wyodrębnienia Galicji (1916-1917), [w:] Galicja. Studia i materiaty, Rzeszów 2015, s. 21-47.

71 J. Dąbrowski, Dziennik, s. 85.

72 W. L. Jaworski, Diariusz, s. 146.

73 J. Hupka, Z czasów wielkiej wojny. Pamiętnik nie kombatanta, Niwiska 1936, s. 236. 
Dlatego wielu Polaków w Galicji przyjęło zdroworozsądkową postawę lokalnego, związanego z krakowskim konserwatystami polityka Mariana Dydyńskiego, który po wydaniu Aktu 5 listopada notował w dzienniku: „choć kto nie wierzy w szczerość tego dokumentu (a Dydyński raczej nie wierzył. D. Sz.) to udawać powinien wiarę w niego i uznać, że jako pierwsza i jedyna enuncjacja publiczna wypowiadająca słowo niepodległość jest pożądaną i w przyszłych międzynarodowych układach z porządku dziennego zepchnąć się już nie da"74.

Akt 5 listopada zrodził w Galicji entuzjazm jedynie „krótkotrwały” - jak przyznawał Ignacy Daszyński ${ }^{75}$. Na dłuższą metę musiał wywołać kryzys w relacjach między monarchią a Polakami - na razie maskowany decyzją Franciszka Józefa o wyodrębnieniu Galicji - a w dalszej kolejności dążności emancypacyjne obliczone na połączenie się z Warszawą. W Wiedniu doskonale to rozumiano. Stąd równoczesny akt o wyodrębnieniu Galicji. Nigdy jednak nie został on wprowadzony w życie. Definitywne fiasko negocjacji w tej sprawie nastąpiło wiosną 1917 r. W maju 1917 r. na zebraniu Koła Sejmowego w Krakowie wydano deklarację mówiącą o odbudowie państwa polskiego składającego się ze wszystkich ziem, z dostępem do morza jako celu polityki galicyjskich Polaków. Deklaracja ta w ówczesnych warunkach ocierała się o zdradę stanu.

W tym sensie Akt 5 listopada oznaczał nie tyko początek międzynarodowego postawienia sprawy polskiej i procesu odbudowy państwowości polskiej, ale również był jednym z elementów dezintegrujących monarchię. Polacy znaleźli się w szeregu narodów, które jak Włosi, Rumuni, Serbowie czy Niemcy, poza granicami władztwa Habsburgów miały swoje narodowe państwa ${ }^{76}$. Dokładnie tak sprawy postrzegał austriacki uczony i polityk Josef Redlich. W swym dzienniku obawiał się, że akt może być początkiem rozczłonkowania monarchii ${ }^{77}$. Moment ten podnosił Michał Bobrzyński w swej pracy Wskrzeszenie państwa polskiego. Przypomnijmy - jako środek ratunkowy zaproponował on wydanie aktu wyodrębnienia Galicji ${ }^{78}$. Środek ten mógł złagodzić ból, lecz nie uleczyć chorobę.

\footnotetext{
74 Pamiętnik Mariana Dydyńskiego z Raciborska (1843-1920), Kraków 2015, s. 352-254.

75 I. Daszyński, Pamiętniki, t. II, s. 250.

76 Problematyka ta szczegółowo omówiona w: H. Batowski, Rozpad Austro-Wegier 1914 -1918. Sprawy narodowościowe i działania dyplomatyczne, Kraków 1982.

77 J. Redlich, Schicksalsjahre Österreichs 1908-1919. Das politische Tagebuch Josef Redlich. II. Band 1915-1919, Gratz-Köln 1954, s. 154.

78 M. Bobrzyński, Wskrzeszenie państwa polskiego. Szkic historyczny, t. I. 1914-1918, Kraków 1920, s. 112-113.
} 
Fiasko jego misji jako ministra dla Galicji, który faktycznie miał owo wyodrębnienie przygotować i przeprowadzić, było tego najlepszym dowodem. Niemniej jeszcze jesienią 1917 r. powrócono do pomysłu idei austro-polskiej. Tym razem w formie unii personalnej. Rzeczywistym końcem wszelkich realnych austro-polskich pomysłów - jak podnosił Włodzimierz Suleja - był pokój brzeski z Ukrainą zawarty w lutym $1918 \mathrm{r}^{79}$. Choć zanikająca garstka zwolenników austro-polskiej koncepcji wegetowała jeszcze późnym latem $1918 \mathrm{r}^{80}$

Omawiając całokształt spraw polskich w polityce Austro-Węgier, a kwestię wydania Aktu 5 listopada 1916 r. w szczególności, trzeba uwzględnić jednak jeszcze jeden czynnik, a mianowicie jakie miejsce zajmowała kwestia polska w kompleksie problemów, przed którymi stały władze monarchii? Gdy przejrzymy wydaną przed kilku laty potężną monografię autorstwa Manfreda Rauchensteinera pt.: Der Erste Weltkrieg und das Ende der Habsburger Monarchie okazuję się, że niewielką ${ }^{81}$. Polska problematyka pojawia się fragmentarycznie, natomiast o Akcie 5 listopada możemy przeczytać zaledwie w dwóch miejscach. Pytanie, czy jest to perspektywa autora skoncentrowanego (przy braku znajomości języka polskiego i dorobku polskiej historiografii) na innych sprawach, czy roszczący sobie do obiektywizmu pogląd na stan rzeczy? Sądząc po ilości dokumentów odnoszących się sprawy polskiej w okresie Wielkiej Wojny, nie była ona aż tak marginalną.

Nadesłany: 27 II 2017

Nadesłany po poprawkach recenzyjnych: 10 V 2017

Zaakceptowany: 26 V 2017

Dr hab. Damian SzYMcZaK, prof. UAM,

Instytut Historii

Wydział Historyczny

Uniwersytet im. Adama Mickiewicza

ul. Umultowska 89d, 61-614 Poznań

79 W. Suleja, Ostatnia próba obrony austro-polskiej koncepcji, [w:] Z dziejów Galicji, Ślaska, Polski i Niemiec, red. M. Czapliński, Wrocław 1994, s. 175.

80 O ściste połaczenie Galicji z Królestwem. Wyniki zjazdu krakowskiego, Gazeta Wieczorna nr 4339 z 4 IX 1918, s. 1; W. Suleja, Ostatnia próba obrony, s. 176-177.

81 M. Rauchensteiner, Der Erste Weltkrieg und das Ende der Habsburgermonarchie 1914 -1918, Wien-Köln-Weimar 2013. 


\section{"A bit too late and too little, but at least it's something". Poles in Galicia's attitudes towards the Act of $5^{\text {th }}$ November 1916}

During the outbreak of WWI, a majority of Poles in Galicia were in favour of the Austria-Poland solution. They hoped that once the Kingdom of Poland was taken away from Russia, Franz Joseph I would become the king of Poland. As a result, a new and powerful state would emerge: Austria-Hungary-Poland. In order to pursue this idea, Poles established the Supreme National Committee and the Polish Legions, a military force. Austria's military defeats and general weakness of the monarchy put an end to these plans as the politicians in Vienna failed to be equally willing to pursue the solution. The initiative regarding the Polish cause was taken over by Germans and the Act of $5^{\text {th }}$ November was proclaimed. This indicated that the reconstruction of the Polish state would be modelled by the Reich rather than the Habsburg monarchy. On the one hand, the proclamation of the Act of $5^{\text {th }}$ November was welcomed in Galicia: it was the first document taking the Polish cause to the international arena. On the other hand, the end of the Austria-Poland idea led to resentment. Poles in Galicia were afraid that they would be left outside the new Polish state.

Translated by: Ewa Dratwa 